\title{
Performance of Commercial Banks Profitability in Jordan (2005 -2019)
}

\author{
Osama M. Alalaya ${ }^{1 *}$, Dr. Anwar Ahmad ${ }^{2}$ \\ ${ }^{\mathrm{T}}$ PhD Student, Aligarh Muslim University, Aligarh, Uttar Pradesh 202001, India \\ ${ }^{2}$ Professor, Aligarh Muslim University, Aligarh, Uttar Pradesh 202001, India
}

\section{*Corresponding Author}

Osama Mohammad Alalaya

\author{
Article History \\ Received: 28.05.2020 \\ Accepted: 06.06.2020 \\ Published: 30.06.2020
}

\begin{abstract}
The commercial banks remain one of the important keys of financial intermediaries that provides Variety of services in the economy over the states around the world, therefore this paper aims to investigate the profitability of Jordanian commercial banks in Jordan. The effect of internal and external determinants of Commercial Jordanian Banks profitability has been studied in this paper, the paper utilized of annual time series both internal and external data of these determinants for the period 2008 to 2018. Using the time series analysis and panel data techniques to measure the impact of these determinants, the sample consists of 21 Banks, followed for 14 years the quantitative method in this paper focuses on the statistical. The $\mathrm{R}^{2}$ determinants within are $64 \%$ and LSD $\mathrm{R}^{2}$ is $76 \%$ thus in both $\mathrm{R}^{2}$ the independent variables interpret the changes which happen in ROE, and the $\mathrm{R}^{2}$ is good to do this the analysis and lags depend on Hanan-Quinn which is 67.72042. The groups have a common intercept and the LSDVF 3.658 is > than P-value we reject the null hypothesis, and accept the alternative hypothesis that there is a relationship between ROE and vector of (bank specific). Results indicate that for bank-specific which consist of four variables such as, credit risk, equity, loan, saving the deposit. Where the industry-specific consist of market concentration, and also the macro-economy, determinates include: GDP Per capita, lending interest rate, inflation-unemployment ratio, Total Government revenue / GDP. Money supply ${ }_{2}$. The analysis shows that bank-specific has a positive significant sign to bank profitability. While the market concentrates have appositive effects. Meanwhile, the macroeconomic variables are beyond the scope of management control and show appositive signs.
\end{abstract}

Keywords: Internal and external of banks determinants profitability, bank-specific variables, industry-specific, macroeconomic variables, commercial banks on Jordan, panel data.

\section{INTRODUCTION}

\section{Research Problem}

Both micro and macro levels of the economy has been appraised the bank profitability and the micro level, profit is essential prerequisite for these comparative banks it not merely a result, but it is a necessity for bank growing in a competition in financial markets, therefore the main objective goal for a bank's management is to make a high level of profits. Profitability banks can be in better withstands against negative shocks and can be contributed to the stability of the financial system in the country. Both micro-and macro-levels has compelled researchers, they have conducted their studies on the determinants of bank profitability focus.

\section{Objectives of the Study}

The study conducted to have the impact of the determent variables of profitability in Jordanian banks, according to this objective there is a specific objective of this paper.

1. Analysis of the effect of market concentration (industry - specific variable).

2. To examine the bank-specific variables which are (equity ROE, ROA, loans, saving the deposit, credit risk).

3. To analysis the macroeconomic variables effects on profitability such as; inflation, interest rates, GDP perceptive and unemployment rates during the period of study. The sample which was purposely chosen comprises the three

Copyright @ 2020: This is an open-access article distributed under the terms of the Creative Commons Attribution license which permits unrestricted use, distribution, and reproduction in any medium for non commercial use (NonCommercial, or CC-BY-NC) provided the original author and source are credited. 
levels of banks in the country, which are respectively the commercial local banks, the specified variables are obtained from the financial statements reports of central banks of Jordan, and the Jordanian society banks.

\section{Limitation of Study}

The limitation of this study was representing with limitation of variables which can be added to the study such as the manager of banks effort, the behaviors of bank employee in dealing with costumes, also the regularities of loan and deposits, and the legged launders ratio in this study we cannot carry all these impacted variables.

\section{Previous Studies}

Various studies respectively considered the bank size as an internal factor that influence the performance on one hand, and considered that greater bank size can generate economies of scale, this means that the large organization is often affected by rigidities bureaucracy and inertia [1]. Akbas [2], concluded that higher solvency will reduce the leverage effect, and considered this process it will increase the financing costs. Where others, such as [3] have concluded in their paper that liquid assets, bring low return, consicounitly lower the profitability loans to consumer deposit ratio as a proxy for the liquidity risk, therefore the bank with proper liquidity levelly will have the possibility to meet its obligations. The market concentration as an industry-specific factor is a proxy to some of the squares of the market share of the banks [4]. To test the hypothesis regarding the effects of local markets structure on the various measure of banks performance especially on ROA and ROE.

The drawback of ROA is the existence of the balance - sheet assets [5], proved that it's an important source of the profit for European banks, in their study. While [6] argued that ROE is more important and give it more appropriate in their study, they have mentioned that the use of a yearly average of values of equity and assets expresses the performance more than accurate than the end of year values. While the external factors, that are the macro-economic variables conditions influence the bank profitability, economic growth expressed by the GDP per capita growth many researchers emphasize that multiple consequences among which is the increase both customer deposits and loans which can generate of the interest margins which has a positive impact on bank profitability according to macroeconomic theory, when the economic increased, the demand function for loans and deposits increased, and inflation rates determine the increase of loan interest rate, which can be a results of demand for loans and deposits. All these factors can be a viseversa, also an increased situation a positive effect of the profit margins, where the inflation rate which is not anticipated, it may increase financing costs and affect the bank profitability, also the opposite reset when inflation is anticipated. Boyd and Runkle [7], studied the bank performance and concluded that inverse relationship exists between size of banks and its profitability, while other authors such as [8-11] have a similar results the former shows that firm size impacts banking profitability negatively for large banks, while positively for small banks while medium-sized banks earn the highest returns. This result led us to suggest that the inter-bank market is competitive and efficient.

Demirguc-Kunt and Huizinga [12], have a comprehensive study which examines the determinants of banking performance for so countries both developing and developed countries; for the period 1988-1995 their results indicates that foreign banks have higher profitability than local banks in developing countries and the overall results show support for positive impacts between capital ratio and financial performances.

Demirgue-Kunt and Huizinga [12], have utilized linear regression on commercial data of 80 countries, their study results concluded out a positive but insignificant impact of macroeconomic factors on banks profitability. Where [13] employing the GMM estimator approach; they fund out the appositive significant effect of inflation and the real interest rate on the profitability of Greek banks.

Flanini et al., [14] find out that higher returns on assets are associated with Parge bank size as large size bank in their sample, other results indicate to the bank returns are determined by macroeconomic variables. Naceur [9], using balanced panel data, using lo major deposit banks, the result of study expressed that insignificant impact of inflation rate and annual growth rate on Tunisian banks, but [15] find that there is a significant positive effect between return on assets and the bank size, and other results are the same impacts such as net interest rate margin and exchange rate, total equity, total assets and negative relationship between ROA of the banks and annual growth rate for GDP and inflation rate.

Menicucci and Paolucci [16], they have analyzed the relationship between bank-specific factor and profitability in the European banks sector in order to determine the impact of internal variables, they have implied of a regression analysis that was done on unbalanced panel data set to 28 European banks, for the period 2006-2015 their paper results indicates that capital adequacy ratio and bank size has a positive impacts on bank profitability, also banks with higher deposit ratio tends to be more profitable. Ozgur and Gorus [17], investigated the impact of bank-specific and macroeconomic variables on deposit bank profitability in Turkey, the OLS methodology is implied, monthly data for the period over 2006: 1 to 2006:2 results suggested that equity over total assets, non-performing loans to total cash loans, net interest revenues to total average assets, all factors have a significant impact over return on assets (ROA). 
Many authors studied the determinants of banks profitability such as Sharma and Mani [18], who studies the determinants of banks profitability on Indian commercial banks from 2006 to 2011, the results indicate that the effect of GDP and inflation on banks profitability are negligible. Fewer studies have been conducted regarding the evaluation of banks performance in developing economies $[14,19,20]$ recommended that future studies should be focused more on country-specific studies.

Internal factors of banks profitability determinants refer to the indicators derived from financial statements of banks (balance sheet and income statement) and therefore can be regarded as a specific factor of banks profitability as [21].

This paper is organized as 5 sections, the first section included the introduction, and the second section presents the literature review and the theoretical concepts. The third section represents the data sources and methodology, which described the econometric model and the variables which affect banks profitability section four presents the results of regression analysis and discussions, finally, section five contains the concluding remarks.

Table-1 represents some related studies and the model s of studies also results of these studies.

Table-1: Some previous studies of banks profitability

\begin{tabular}{|l|l|l|l|l|}
\hline Authors & Country & Models \& Procedures & Results & Year \\
\hline $\begin{array}{l}\text { Goddard } \text { et al., } \\
\text { [6] }\end{array}$ & $\begin{array}{l}\text { 6 EU } \\
\text { countries }\end{array}$ & $\begin{array}{l}\text { Generalized Method of } \\
\text { Moments (GMM) }\end{array}$ & $\begin{array}{l}\text { Determined that there is a positive relationship } \\
\text { between bank size and profitability }\end{array}$ & 2004 \\
\hline $\begin{array}{l}\text { Al-Jafari and } \\
\text { Alchami [22] }\end{array}$ & Syria & GMM & $\begin{array}{l}\text { Reached a conclusion that inflation rate and } \\
\text { economic growth affect bank profitability }\end{array}$ & 2014 \\
\hline $\begin{array}{l}\text { Aftab } \text { et al., } \\
\text { [23] }\end{array}$ & Pakistan & Regression & $\begin{array}{l}\text { Reached a conclusion that private banks are more } \\
\text { profitable in comparison with others }\end{array}$ & 2015 \\
\hline $\begin{array}{l}\text { Hu and Xie } \\
\text { [24] }\end{array}$ & China & $\begin{array}{l}\text { Modeling Structural } \\
\text { Equation Modeling }\end{array}$ & $\begin{array}{l}\text { Concluded that risk-taking is positively related to } \\
\text { tor profitability. }\end{array}$ & 2016 \\
\hline $\begin{array}{l}\text { Islam and } \\
\text { Nishiyama [25] }\end{array}$ & South Asia & GMM & $\begin{array}{l}\text { It was defined that interest rate positively affects } \\
\text { bank profitability }\end{array}$ & 2016 \\
\hline $\begin{array}{l}\text { Aydemir and } \\
\text { Oven [26] }\end{array}$ & Turkey & Regression & $\begin{array}{l}\text { Understood that bank profits in Turkey are } \\
\text { sensitive to interest rates }\end{array}$ & 2016 \\
\hline $\begin{array}{l}\text { Lipunga [27] } \\
\text { Malawi }\end{array}$ & Regression & $\begin{array}{l}\text { Defined bank size as the most important factor of } \\
\text { bank profitability }\end{array}$ & 2014 \\
\hline $\begin{array}{l}\text { Boitan [28] } \\
\text { Eetria } \text { et al., }\end{array}$ & $\begin{array}{l}\text { European } \\
\text { [29] }\end{array}$ & $\begin{array}{l}\text { Granger Causality } \\
\text { Analysis }\end{array}$ & $\begin{array}{l}\text { Defined GDP growth rate as having a positive } \\
\text { and high influence on the profitability of banks }\end{array}$ & 2015 \\
\hline $\begin{array}{l}\text { Alalaya \& } \\
\text { Alkhtab [30] }\end{array}$ & Jordan & $\begin{array}{l}\text { Pegression } \\
\text { (fixed effect, random } \\
\text { effect) }\end{array}$ & $\begin{array}{l}\text { Identified economic growth as a significant } \\
\text { indicator of bank profitability. }\end{array}$ & 2015 \\
\hline $\begin{array}{l}\text { Defined GDP per capita as a positive influence } \\
2013\end{array}$ & 2013 \\
\hline
\end{tabular}

Sources: Conducted by authors depends on previous studies of authors papers.

\section{Section two: The Economic State of Banks In Jordan}

\section{Commercial Banks and Situation of Interest Rate, Deposits, Loans}

The study takes in account 16 local commercial banks in Jordan, the foreign commercial banks are not considered in the study some of the banks are established in 1930, and 1960, 1999, and some are newly established such as maturational Islamic Arab bank (1977) and Islamic spwat bank (2010). The situation of the same indicator in (20142017): in this part, we have to study the modern changes in interest rate credit facilities', deposits, loans than previous the facilities in Jordan commercial banks. On Feb. 2, 2017, the central bank of Jordan (CBJ) raised the interest rates on its monetary policy tools by $50 \mathrm{bps}$. The statement issued by the (CBJ) cited the global development and the rising competitive pressure on the Jordanian Dinar as main drivers behind this decision. This aggressive decision is a hawkish sign that aim at setting the stage for more interest rate hikes in the (CJB) bank aims to closely monitor to the natural activity in the money market, and to enhancing the attractiveness of the JOD denominated saving vehicles. Two large banks are gain from this policy the housing bank for trade and finance (THBK), particularly Arab Bank (ARBK) and Cairo bank -Amman, they are the best interest rate, this also allows other banks to enjoy ample excess their liquidity. The medium and small-sized banks would point to have the completion on deposits and have a chance of bank money market, but this would be underperforming of the bank. The interest rate on demand deposits inched by a slight 7.5 bps during the period of study, and slightly in 2017, $20184 \mathrm{bps}$ while interest rate on saving and time deposits slightly slipped by $3.62 \%$, but it remained stable at $0.56 \%$ and $3.04 \%$, respectively the interest rates on overdrafts and loans $\&$ advanced expanding by 40 bps. Figure-1 illustrated these changes. 


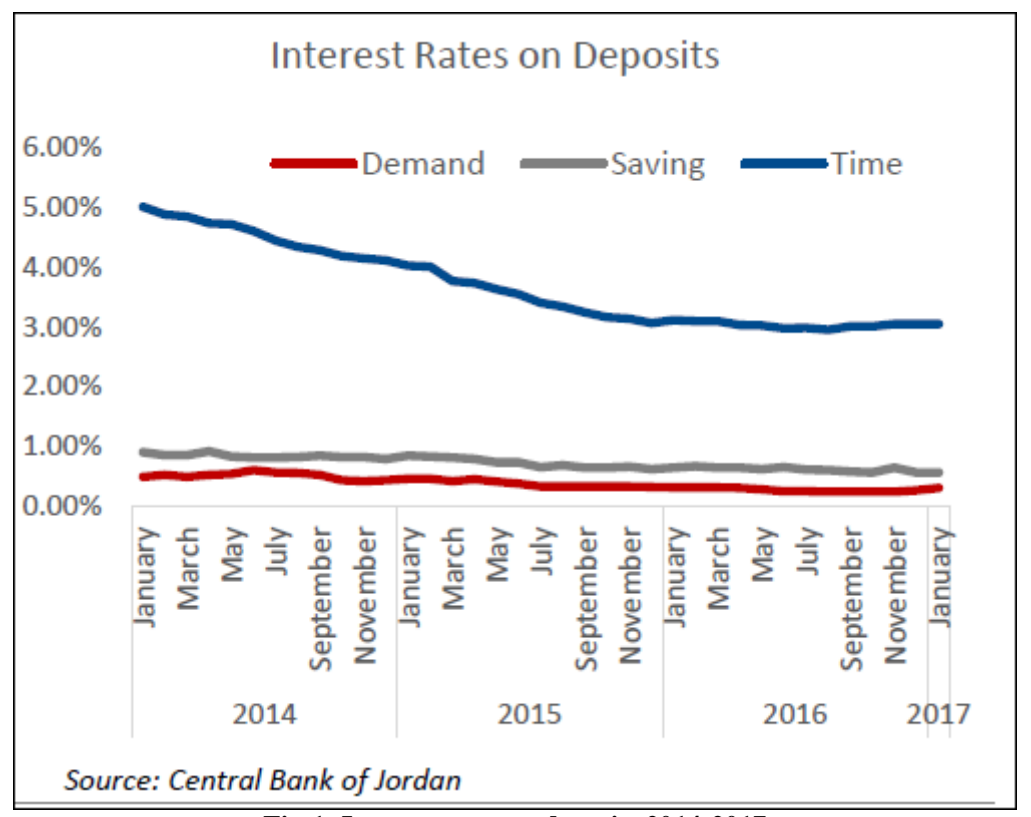

Fig-1: Interest rates on deposits 2014-2017

Source: Central Banks of Jordan Annual report 2018

The money supply (M1) tumbled sharply in 2016 and 2017 years, falling by $3.4 \%$ MoM, on the back of $2.4 \%$ decline in currency with the public, coupled with a $3.9 \%$ drop in JOD denominated demand deposits.

The drop- of M1 was the main culprit behind the steep decline in M2 which posted it is the biggest monthly drop since November 2012, falling by $0.8 \%$ MoM. Also, the foreign currency reserves stand at USD 12.9 billion, a drop of USD 700 million the foreign currency cover 6-8 months of kingdom's import beyond the IMF supported which considers it the cornerstone behind economic stability in Jordan economy. The following Figure-2 shows the FC reserves by US dollars.

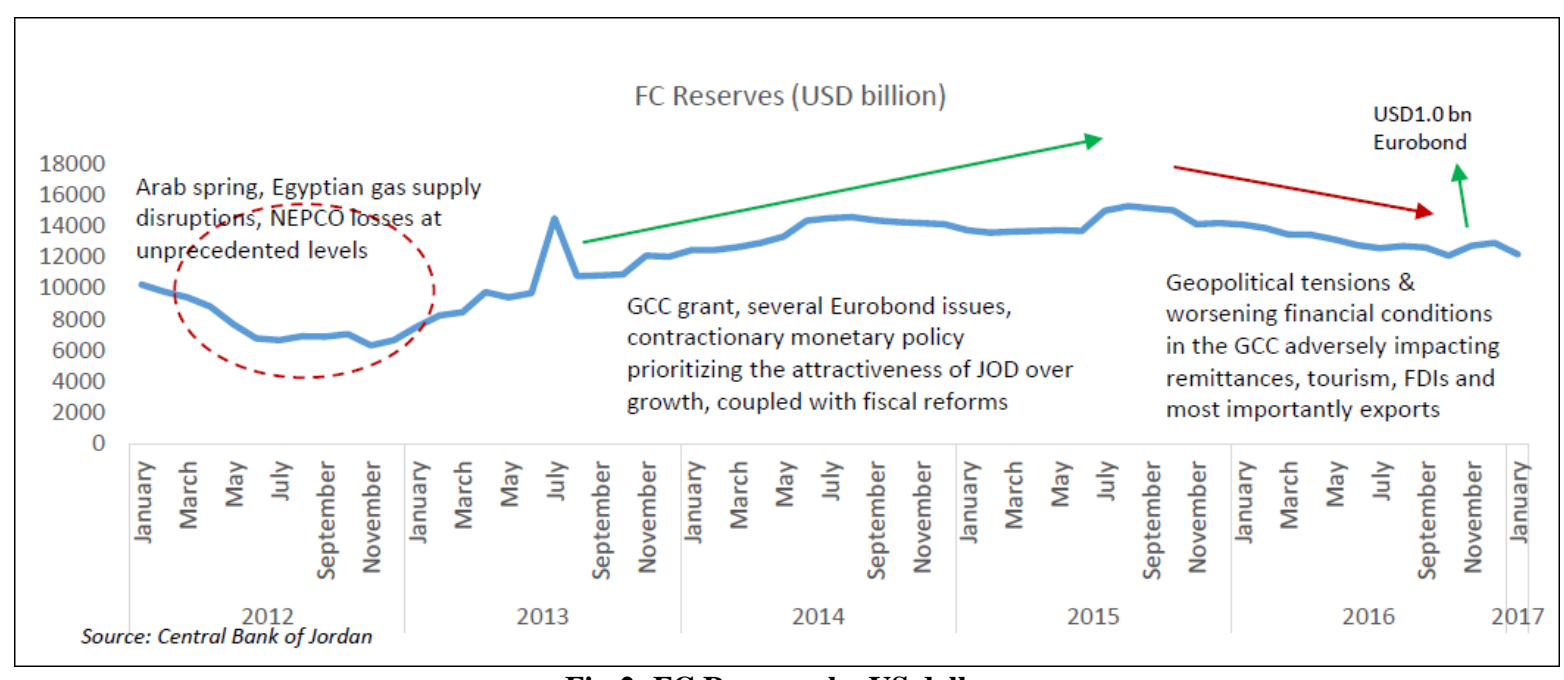

Fig-2: FC Reserves by US dollars

Source: Statisitics department of Jordan, and Central Bnk of Jordan 2018.

The grow of indirect credit facilities $(0.6 \% \mathrm{MoM})$. The deposits growth slipped down, even though there is volatility of grow year to year this can appear will from the Figure- 3 of total deposits. 


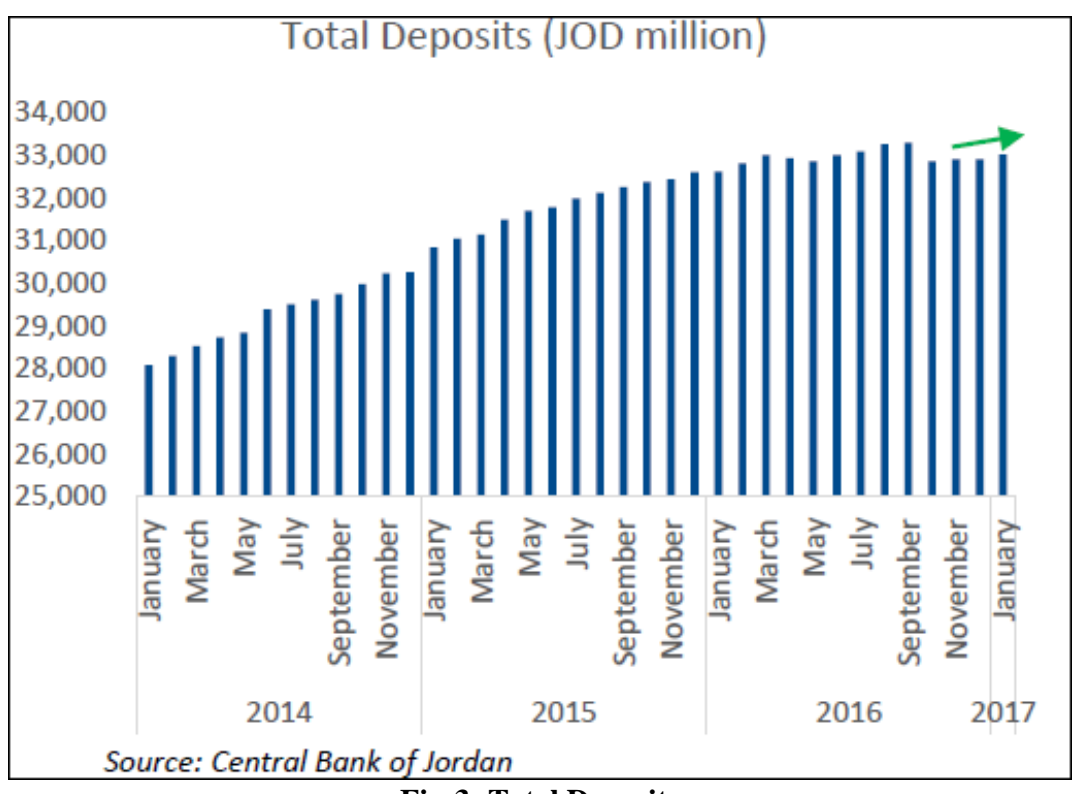

Fig-3: Total Deposits

Source: Central Banks of Jordan annual report 2018.

The domestic credit of 2014 - 2017 also the growth in domestic credit can give us a sign of the domestic credit growth for all study period growth Figure-4 shows the domestic credit.

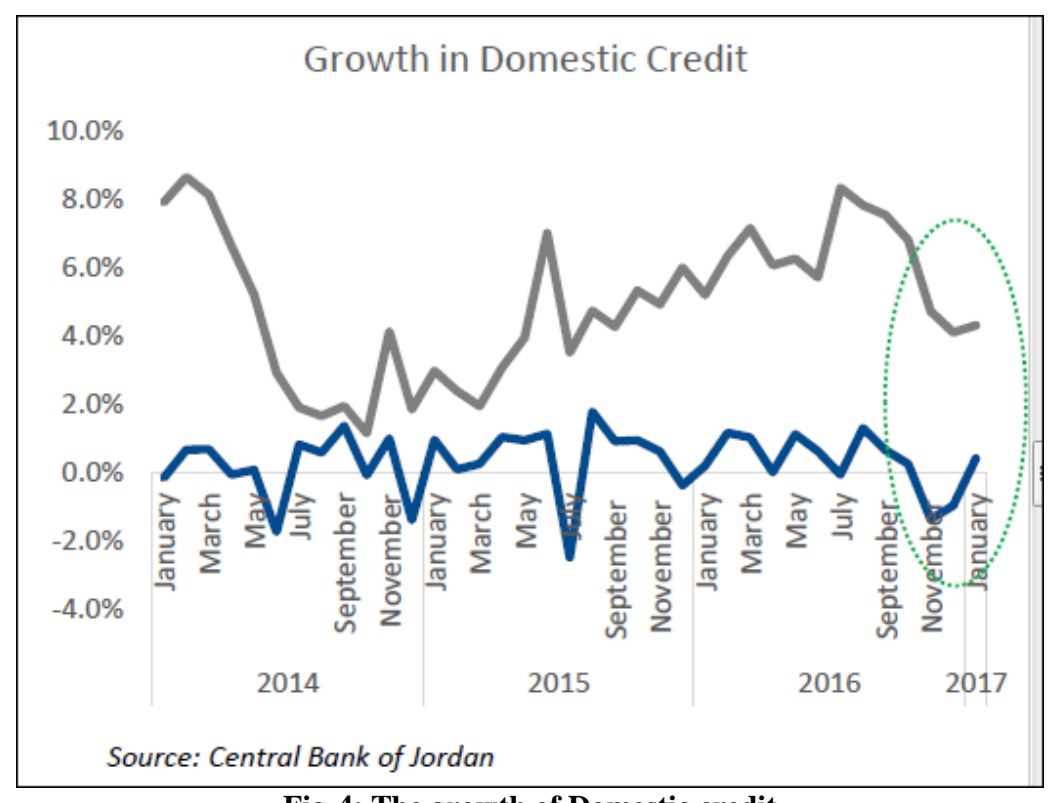

Fig-4: The growth of Domestic credit

Source: Central Bank of Jordan annual report 2018.

\section{LITERATURE REVIEW}

MC Cauley and white [31] have studied the merger and acquisition activity in the UK banking sector, the period of their study from 1991 to 1996. Levine, 1997, shows the efficacy of financial intermediation can growth while at the same time bank insolvencies can result in systemic crises which have adverse consequences for the country as a whole.

Low levels of liquidity and poor assets quality are two major causes of bank risk, and cause lastly can be divided into credit and liquidity risk. Many authors refer to the relationships between the level of liquidity and profitability. Also, the effect of credit risk on profitability has a negative impact [32].

Several studies that have analyzed the determinants of bank profitability $[33,34]$, suggested in their study that banks in EMEs are relatively similar to their economy's counterparts. The difference between ROA is tended to reflect factors such as two underlying changes in leverage. Ramtall [35], additionally took into consideration the influence and 
theories on the determinants of bank profitability. Goddard et al., [36] who said that the banking sector is relatively scant. Other studies were related to the profitability issues persistence in the bank industry such as [37, 36], they are focused in their studies on a relatively small number of predominantly developed countries. Flamini et al., [14], they have investigated the bank profitability by using a panel data set. Casu et al., [38] mentioned in their studies that the banks play a central function in the economy, banks keep the finance of business, trade and keep the saving of the public sector.

Khrawish [15], has shed lights on the bank profitability the period of study from 2000-2010 the result of the study emphases that there is significant and positive relationships between total, liabilities to total assets, bank size total equity total assets the macroeconomic variables who are considered as external variables such as annual growth rate of GDP and inflation have a negative impacts with profitability. Dietrich and Wanzonries [39], have in their study negative relationship could be that as the banks are becoming extremely largely the bureaucratic procedures have negatively affected their performances. Finally, we can conclude in the following table () some studies that related to the profitability.

\section{Definition of Variables \\ Macroeconomic Variables \\ Unemployment Ratio}

Figure-5 shows the volatility of unemployment ratio year to year according to the government statics, but in fact is more than the government scan of unemployment in Jordan, we see that the female ratio is doubled of male ratio with so grads to other macroeconomic variables the unemployment rates effects on profitability as negative influence of ROE and ROA. Hence; the ratio is expected to have a negative relationship with profitability.

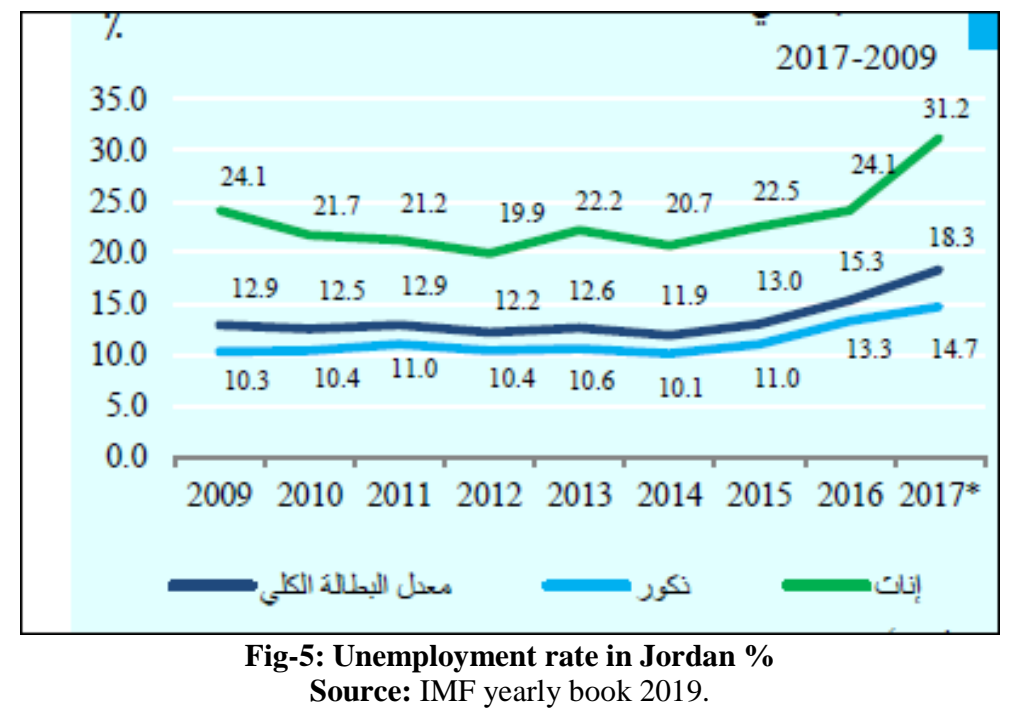

\section{GDP Per Capita}

It is adjusted for the activity of persons in Jordan, money reserve and economic activities in Jordan it spouse to be a positive effect, due to related to it's the demand and supply for bank loans and deposits.

Where the Mathematical calculation of factors (derivative) as below:

\section{Inflation Rate}

This variable can measure through the overall percentage increase of the level of prices index, for all goods and services in Jordan, in fact, the inflation rate affects the real costs and revenues, most studies indicate to positive impacts between profitability and inflation rate.

\section{Interest Rate}

Most previous studies proved that a positive impact between interest rate and bank profitability, bans can increase profits when they rising interest rates. Therefore, the interest rate expected to have positive impacts with banks profitability. Loan on loss provision as a percentage of total asset $\partial \prod / \partial$ LLPTA $<0$. Therefore, liquidity can be measured as one of below:

1. Loan as a percentage of deposits. This can be obtained by $\partial \prod / \partial$ loan $\mathrm{D}$

2. Loan as a percentage of total assets. $\partial \Pi / \partial$ loan $\mathrm{TA}>0$. 
Operational efficiency: it can be measured as:

1. N1 MOPEX: Net interest margin as a total operating expense. It can be measured as $\partial \prod / \partial$ NIM $>0$.

2. Operating expense to total assets is expected that $\partial \prod / \partial$ OPEXT $:>$ or $>0$ when the bank higher operative expense per dollar or dinar assets the profitability of bank declines.

Bank size: There is the number of indexes for measuring a bank size:

- Total loans, or total assets, total deposits can be measured a large size of a bank or small size or either may enjoy economics or dis-economic scales.

- Total assets.

- Total deposits, therefore, the sign of relationship can't be a priority determined between the profitability and $\partial \prod / \partial \log \operatorname{dep}=\partial \Pi / \partial \log$ loan $>0$ other wise $\partial \prod / \partial \mathrm{TA}=\partial \Pi / \partial \log$ depo

bank size. It can be as $=\partial \prod / \partial \prod \operatorname{logloan}<0$.

\section{Capital Efficiency}

It represents a verse bank risk aversion index, it measured by banks equity. The higher amount of equity capital to total assets, the higher the risk a version of the bank and it implies low law leverage, therefore low profits, thus it can be as $\partial \prod / \partial>0$ EQTA

\section{GDP Per Capita}

The growth of demand is lead by increasing of GDP per Capita, and this comes by economic growth which can finance more loans, this process can increase the bank profitability, is expected to have a positive sign and can obtain by $\partial \prod / \partial \mathrm{GDP}>0$. Inflation and interest rate, the higher value of CPI and interest rate can increase the bank profitability $\partial \prod / \partial \mathrm{P}>0$.

The inflation and interest rate expected to have positive relationships with bank profitability.

\section{Bank -Specific Variables}

We can be considered the internal factors are bank's management decisions, and bank policies; these variables, such as capital adequacy, liquidity deposits, bank size; loans.

\section{Capital Adequacy}

It indicates capital strength, it measured by the ratio of equity to total assets. It also indicates to the bank can handle the risk exposure of processes. It also expected to have a positive impact on banks profitability.

\section{Liquidity}

This ratio measured by the divided ratio of loan to deposits, insufficient liquidity is the major reasons of bank failures some research finds the positive impacts, the banks can use the higher liquidity to mitigate the risk.

\section{Bank Size}

The positive effect link the relationships between bank size the imply of bank size can increase the profitability of the bank, and can make the sense of bank use from the community; some researchers find that the bank size the big and medium size can increase their profit, but up to point of profit, and after can be inverse relation to the costs. Some of them are negative relation $[5,14,11]$ according to these studies banks can insert and existence economies and diseconomies of scale.

\section{Nonperforming Loans}

The poor assets quality and low level of liquidity are beyond of other cause to the bank to failures. Some researcher has expected to have the inverse link between bank profitability, the bank profitability will increase when the bank is law exposed by credit ratio risk this can be measured nonperforming loan to total loan ratio.

\section{Coverage Ratio}

This internal factor indicates a ratio of coverage of nonperforming debts of the bank, is expected to be a positive significant relationship with banks performance. 


\section{The Framework of the Study}

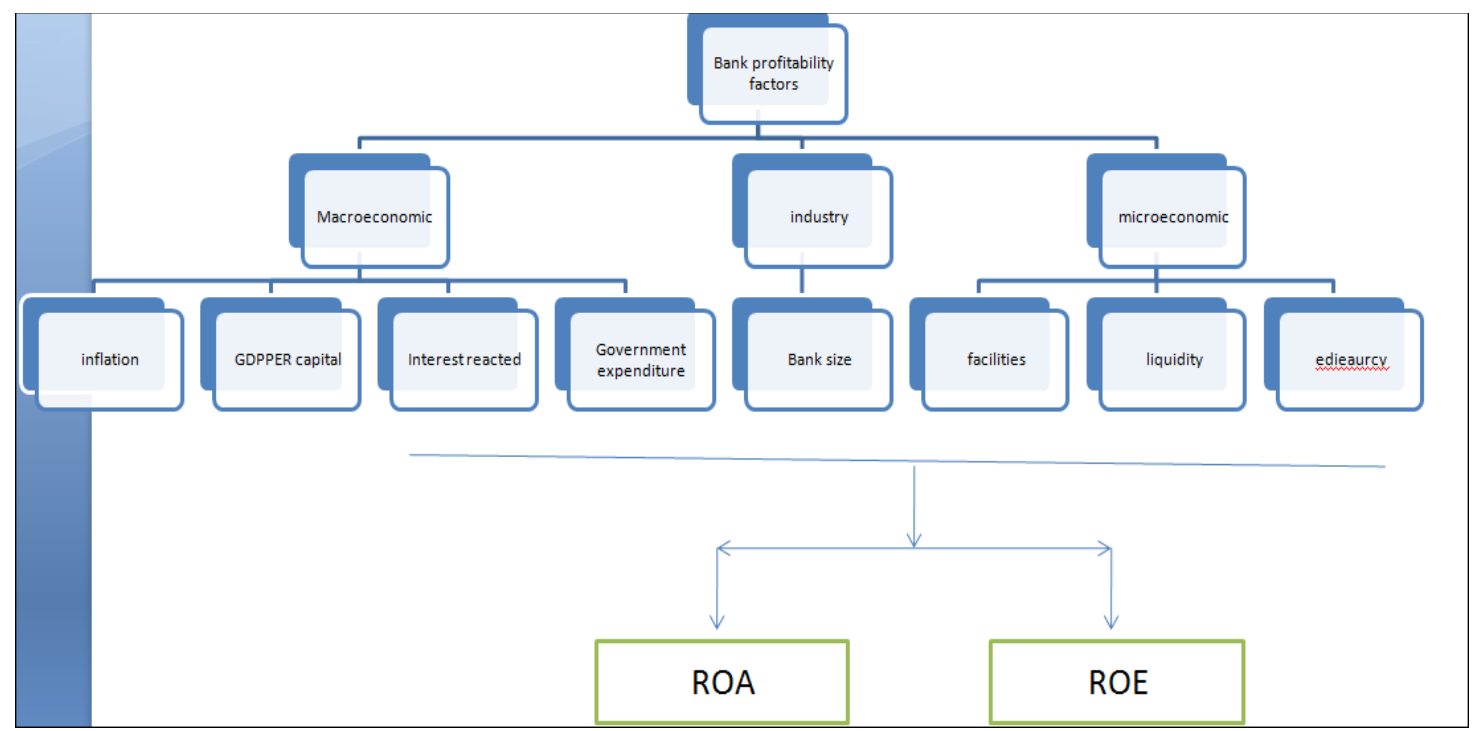

Fig-6: The framework of this study is available

Source: Conducted by authors

\section{Section Four: Data and Methodology}

1. The central bank of Jordan- several monthly issues related to the study period, and the annual report since $2004-$ up to2018.

2. I.M.F reports 2009 -2016 which related to CPI, and employment ratios.

3. D.O.S of Jordan.

4. Jordanian banks society.

The methodologies are represented in fixed effects, and random effects methods and analyze the result to check the impacts of variables. The macro and microeconomic variables in both ROA and ROE.

\section{Section five: Empirical results and discussions}

1. The first step is to testify the statistics of variables, the statistics are available in Table-2.

Table-2: Statistical report of all variables of the study

\begin{tabular}{|l|l|l|l|l|}
\hline Variables & Mean & Std. Dev. & Skewness & Ex. kurtosis \\
\hline GDPCapita & 2.40761 & 0.545410 & -1.33891 & 0.855535 \\
\hline Capadequacy & 18.3636 & 1.29080 & -0.814668 & -0.0454519 \\
\hline Inflation & 0.0599393 & 0.0169956 & 0.183393 & -1.21843 \\
\hline UNEMPLYRate & 16.6086 & 2.01896 & 0.955503 & -0.129517 \\
\hline Goexpeno/GDP & 27.8521 & 3.60160 & -0.608667 & -0.727822 \\
\hline Coverage ratio & 69.5357 & 10.9456 & -0.649493 & -1.00923 \\
\hline grfacilities & 11.3071 & 7.79077 & 0.917397 & -0.193216 \\
\hline liquidity & 1.54014 & 0.160595 & -0.829636 & 0.964542 \\
\hline Nonperfom & 6.21286 & 2.01330 & 0.575320 & -0.595125 \\
\hline ROA & 1.28571 & 0.320713 & 0.569516 & 0.316952 \\
\hline ROE & 11.2500 & 3.40627 & 1.74912 & 2.61521 \\
\hline
\end{tabular}

In the Table-2, all variables are in normal distribution nearly, and all variables means are normal according to the data itself, the standard deviation is in most of the sample less than $25 \%$ of mean this means the panel data is in a good position to analyze, the skewness and ex. Kurtosis with normal limits.

2. Fixed effect model: The fixed effects model allows the partial regression coefficients to become cross-sectional units, while the random effect model assumed that a common mean value of intercept (C) exists, and the cross-sectional difference in each bank reflected in the error term $\sum \mathrm{t}$. therefore the two models are utilized in this paper to have the right correlation and coefficient links between mean cross-sectional internal and external factors which are affected the profitability of banks in Jordan. 


\section{A - ROE and bank specific; The estimation equation is:}

$\mathrm{ROE}=-16.1118+4.9488$ liquidity +0.1056 coverage ratio +0.067357 grfacilities +0.8993 capadequacy 0.7857 Nonpeform.

Table-3: Represents the specific results

\begin{tabular}{|l|l|l|l|l|}
\hline p-value & t-ratio & Std. Error & Coefficient & \\
\hline 0.5771 & -0.5846 & 27.5589 & -16.1118 & const \\
\hline 0.4424 & 0.8140 & 6.07939 & 4.94884 & liquidity \\
\hline 0.4338 & 0.8302 & 0.127241 & 0.105638 & Coverageratio \\
\hline 0.6776 & 0.4337 & 0.155318 & 0.0673576 & grfacilities \\
\hline 0.3704 & 0.9571 & 0.939613 & 0.899281 & Capadequacy \\
\hline 0.2212 & -1.3430 & 0.585038 & -0.785687 & Nonperfom \\
\hline
\end{tabular}

\begin{tabular}{|l|l|c|l|}
\hline 3.406272 & S.D. dependent var & 11.25000 & Mean dependent var \\
\hline 2.282557 & S.E. of regression & 36.47047 & Sum squared resid \\
\hline 0.643066 & Within R-squared & 0.758209 & LSDV R-squared \\
\hline 0.056864 & P-value(F) & 3.658446 & LSDV F $(6,7)$ \\
\hline 67.13452 & Akaike criterion & -26.56726 & Log-likelihood \\
\hline 66.72042 & Hannan-Quinn & 71.60792 & Schwarz criterion \\
\hline 2.709245 & Durbin-Watson & -0.517807 & rho \\
\hline \multicolumn{4}{|c|}{ Model 18: Fixed-effects, using 14 observations } \\
Dependent variable: ROE
\end{tabular}

The explanation of the results are: all coefficients has positive sign, therefore the relationship between ROE and these variables, Liquidity, Coverage ratio which presents the credit risk, grfacilities of banks, and capital adequacy are proportional and all of these variables are significant due to t ratio > P-value, where Non performing loans has a negative relationship as enviers relationship.

\section{B - The ROA and specific variables the estimation of the function is:}

$\mathrm{ROA}=-2.2993+0.50$ Liquidity +0.0124 coverage ratio - gr facilities +0.1608 capital edecuacy -0.1476 Nobnperform

Table-4: Fixed-effects, using 14 observations

\begin{tabular}{|l|l|l|l|l|l|}
\hline & p-value & t-ratio & Std. Error & Coefficient & \\
\hline & 0.3937 & -0.9088 & 2.53013 & -2.2993 & const \\
\hline & 0.4001 & 0.8959 & 0.558139 & 0.500012 & liquidity \\
\hline & 0.3250 & 1.0585 & 0.0116818 & 0.0123652 & Coverageratio \\
\hline & 0.6248 & -0.5114 & 0.0142595 & -0.0072929 & grfacilities \\
\hline & 0.1044 & 1.8651 & 0.0862643 & 0.160896 & Capadequacy \\
\hline$* *$ & 0.0286 & -2.7481 & 0.0537113 & -0.147606 & Nonperfom \\
\hline
\end{tabular}

\begin{tabular}{|c|l|c|l|}
\hline 0.320713 & S.D. dependent var & 1.285714 & Mean dependent var \\
\hline 0.209558 & S.E. of regression & 0.307401 & Sum squared resid \\
\hline 0.743221 & Within R-squared & 0.770106 & LSDV R-squared \\
\hline 0.048736 & P-value(F) & 3.908138 & LSDV F(6, 7) \\
\hline 0.269045 & Akaike criterion & 6.865477 & Log-likelihood \\
\hline-0.145050 & Hannan-Quinn & 4.742447 & Schwarz criterion \\
\hline 2.428318 & Durbin-Watson & -0.364105 & rho \\
\hline
\end{tabular}

Dependent variable: ROA

The model indicates to proportional relationship between liquidity credit risk (Coverage ratio) and capital adequacy but in other hand enviers relationships between ROA and Non perform and gr facilities the $\mathrm{R}^{2}$ within is $74 \%$ and the LSDV $\mathrm{R}^{2}$ is $77 \%$ this means the determinant ratio is good to interfere the changes of dependent variable (ROA) by the independent vector explained above in the analysis and lags we depend on Akaike criterion results of rho and Durbin Watson give us the stand to say that there is no serial correlation in the model, and F-test value let us to concluded that the model is good to interpret the relationships. 
C - ROE with macroeconomic variables:

According to the results of the Table-5 the estimation of the function of macroeconomic variables is:

$\mathrm{ROE}=25.2698+3.321$ GDP per capita -0.5786 un employ - 0.56715 Geoexy GDP + 56.1647 inflation.

Table-5: Fixed effect of macroeconomic variables of ROE

\begin{tabular}{|l|l|l|l|l|l|}
\hline & $\boldsymbol{p}$-value & t-ratio & Std. Error & Coefficient & \\
\hline & 0.1805 & 1.4672 & 17.2229 & 25.2698 & const \\
\hline 0.2981 & -1.1128 & 0.50965 & -0.567147 & GoexpentoGDP \\
\hline & 0.6558 & -0.4629 & 1.2501 & -0.578614 & UNEMPLYRate \\
\hline 0.4018 & 0.8854 & 3.76233 & 3.33105 & GDPCapita \\
\hline & 0.8289 & 0.2233 & 251.482 & 56.1647 & Inflation \\
\hline
\end{tabular}

\begin{tabular}{|l|l|c|l|}
\hline 3.406272 & S.D. dependent var & 11.25000 & Mean dependent var \\
\hline 3.306317 & S.E. of regression & 87.45385 & Sum squared resid \\
\hline 0.144096 & Within R-squared & 0.420202 & LSDV R-squared \\
\hline 0.404899 & P-value(F) & 1.159581 & LSDV F $(5,8)$ \\
\hline 77.37903 & Akaike criterion & -32.68952 & Log-likelihood \\
\hline 77.02410 & Hannan-Quinn & 81.21338 & Schwarz criterion \\
\hline 1.585747 & Durbin-Watson & 0.048779 & rho \\
\hline
\end{tabular}

Fixed-effects Model, for macroeconomic factors

Dependent variable: ROE

The positive significant relationship between ROE and GDP per capita with 3.33 coefficient and negative relation with unemploy and government expenditure to GDP and a positive relationship with inflation (CPI). LSDV Ftest 1.1596 with P-value. F 0.404, the results indicates to reject the null hypothesis of no linked relation in a positive and negative sign the lagged bused on Hannan-Quinn (77.02410). The rho coefficient 0.048779 and Durbin-Walson is 1.5857 these there is no serial correlation on data LSDv $\mathrm{R}^{2} 0.4202$.

D - Table-6 indicates the relationships between the dependent (ROA) and the macroeconomic dependence variables.

$\mathrm{ROA}=4.4804+0.5241$ GDP per capita-0.14055 un employ rate $-0.058331-8.70383$ inflation.

Table-6: Fixed-effects Model for macroeconomic variables of ROA

\begin{tabular}{|l|l|l|l|l|l|}
\hline & $\boldsymbol{p}$-value & t-ratio & Std. Error & Coefficient & \\
\hline$* * *$ & 0.0093 & 3.4031 & 1.31658 & 4.4804 & const \\
\hline & 0.1727 & -1.4972 & 0.0389594 & -0.0583307 & GoexpentoGDP \\
\hline & 0.1796 & -1.4707 & 0.0955619 & -0.140547 & UNEMPLYRate \\
\hline & 0.1004 & 1.8571 & 0.287606 & 0.534112 & GDPCapita \\
\hline & 0.6628 & -0.4528 & 19.2241 & -8.70383 & Inflation \\
\hline
\end{tabular}

\begin{tabular}{|l|l|l|l|}
\hline 0.320713 & S.D. dependent var & 1.285714 & Mean dependent var \\
\hline 0.252746 & S.E. of regression & 0.511045 & Sum squared resid \\
\hline 0.573113 & Within R-squared & 0.617808 & LSDV R-squared \\
\hline 0.111703 & P-value(F) & 2.586380 & LSDV F $(5,8)$ \\
\hline 5.385310 & Akaike criterion & 3.307345 & Log-likelihood \\
\hline 5.030371 & Hannan-Quinn & 9.219654 & Schwarz criterion \\
\hline 1.731970 & Durbin-Watson & -0.017723 & rho \\
\hline \multicolumn{4}{|c|}{ Dependent variable: ROA }
\end{tabular}

rho coefficient is -0.0177 , and Durbin-Watson 1.7319 , therefore there is no serial correlation in the model, also the $\mathrm{R}^{2}=0.61781$, it explains the variation between dependent and independent variables. The joint test on named regresses is $=2.68508$ with $\mathrm{P}$-value $=0.1093$, thus we reject the null hypothesis of no relation with ROA. The model is good to predict the impact according to $\mathrm{F}$-statistic 2.5864 with $\mathrm{P}$-value $\mathrm{F}=0.1117$, all independent variables except (GDP) per capita which has a positive sign the other variable has a negative sign, this means the inverse relationship a 
ped the relations with ROA, Therefore the results of Government expanse / GDP has a negative sign, also the unemployment ratio where the inflation and the GDP per capita has a positive relationships with ROA. The $\mathrm{R}^{2}=47 \%$ this result is not bad it explains the changes in ROA due to the changes in the macro-economic variables there is no serial collation in the model due to $\mathrm{P}(-0.15537)$. The estimation of macro-economic variables with ROE is:

$\mathrm{ROE}=26.709+3.588$ GDP per capita + 177.87 inflation - 0.6908 Gov. Expense /GDP 0.934 unemployment rate. While $\mathrm{R}^{2}=39.4 \%$, and $\mathrm{R}^{-2}=12.5 \%$ therefore, we can add many effected variables can be impacted the profitability.

The random effect model:

Table-7: Random - effects DLS regression to the period of 2005-2018

\begin{tabular}{|l|l|l|l|l|}
\hline Variables ROA & Coet & Std/Error & $\mathbf{2}$ & $\mathbf{P}>|2|$ \\
\hline Loan & 0.1346 & 0.00954 & 2.43 & 0.009 \\
\hline Cons & -0.2973 & 0.6854 & -0.47 & 0.743 \\
\hline Coverageratio & 0.5271 & 0.2298 & 3.62 & 0.296 \\
\hline Liquidity & 0.3792 & 0.4692 & 4.75 & 0.683 \\
\hline gr facilities & 0.1681 & 0.0262 & 0.978 & 0.396 \\
\hline Nonperforming loans & 0.1027 & 0.3655 & 0.4259 & 0.073 \\
\hline Capital adequacy & 0.0644 & 0.0231 & 0.405 & 0.005 \\
\hline Unemployment & -0.0187 & 0.216 & 0.866 & 0.017 \\
\hline GDP per capita & 0.04558 & 0.0269 & 0.28 & 0.0063 \\
\hline Inflation & -0.1638 & 0.0273 & 0.567 & 0.078 \\
\hline Goexp to GDP & 0.2942 & 0.7021 & 0.25 & 0.574 \\
\hline
\end{tabular}

Within R-squared $=0.3872 \mathrm{R}$-squared between 0.6873

Overall $=0.6488$ Wald test ${ }^{2(\mathrm{q})}$ chi $=91.635$ Prob $>$ chi $2=0.0267$

Table-7 Shows the model has overall 0.65 explanatory power to interpret the variables effects of ROA, therefore the variation of ROA is $65 \%$ by the explanatory variables. The wald test $\mathrm{X}^{2}$ - statistics is 91.635 and its probe-value is 0.0267 , this suggests that the null hypothesis of the slope of all coefficients of explanatory variables are $B_{i t}=0$. Is rejected, and we can conclude that the slopes significantly differ from Zero. The table (_) shows also that bank-specific factors have significant signs and they are consistent, the profitability of banking sector is significantly affected by liquidity, also capitalization, and credit risk (Coverage ratio). Therefore, we can conclude that the bank-specific characteristics such as liquidity, capital adequacy, and credit risk (Coverage ratio) had a positive impact on bank profitability and significant signs.

The signs of GDP per capita are positive also its significant factor impacted profitability while the inflations rate (CPI) has a negative sign and significant, it means that inverse relationship between inflation rate and banks profitability. But the government expense ratio to GDP has a positive sign and significant but unemployment has an effect and the slope is significant.

\section{CONCLUDED REMARKS}

The role of banks remain central in financing economic activities, and its effectiveness could exert positive impacts on the overall economy, some of the internal determinant variables refer to the factor originate from bank accounts, others from costumes, and economic policy of a country, because the external factors are not related to bank management, but it reflects the environment and economic variables, which affects the operations and performance of financial institutions. The empirical results of previous studies concluded that the internal factors explain a large proportion of banks profitability and it is the main source of profitability beyond and nevertheless that the external factors have also an impacts on the performance, but less than internal variables, several factors have been suggested as impacting on profitability, we can through these variables distinguished between control variables of them. That describe the macroeconomic variables Such as interest rates, and cyclical output and GDP Per Capita. Banks can belt a net of social benefits by exploring scale economics, also it can enforce contracts with borrowers, and reduce the delegation costs through a sufficient diversification of their loans, the specialness of banks as driving from the integration credit and liquidity provision functions rather bank's employment efforts.

This paper aims to study the main determinants variables of banks performance in Jordan which evaluated by banks profitability as a result of banks works during a year. Variables or factors are divided into three main categories, first are microeconomic specific variables, second is industry, where third are macroeconomic variables these factors are affected the performance of banks profitability, the size of bank has less impact than other factors, even in small and 
medium-sized banks, but the profit ratios are more than large size banks . The small effects appear of week significance in the case of ROAA. This study proposed determinant variables as available in the frame work; that specifically related to microeconomic and then market concentration, lastly the macro economics To employ with the main objective of this research quantitative methods are applied to the panel data, to do this we applied the fixed effect, and random effect, lastly we applied the fixed effect with dummy variable which represents the stability of monetary policy in Jordan, in order to testify the hypotheses of this study, As the finding ; the liquidity results show it has a negative sign and it provides that there is further implication on the effective risk management practices in Jordan banks, Therefore our suggestion according to the result of study it should be considered the interest rate policy into account as most important key of banks competitions, for that market segment and financial service should be diversification and developed time to time, then banks should be aware of credit risk, and should be managed in a cost effective way, in addition, to choose the propagate bank size, and to have more spread in the country(more branches), lastly to training their employments, to adjust banks activities and deal with costumers. these suggestion are to continuous of reliability of generated stability and improved position of monetary and financial market, finally this research can pursue the future research that unrealistic assumptions about the statistical techniques employed to have the impact results, therefore we expect that others can fly more in the horizon of this field and can do better.

\section{REFERENCES}

1. Kosmidou, K. (2008). The Determinants of Banks' Profits in Greece during the Period of EU Financial Integration, Managerial Finance. 34:146-159.

2. Akbas, H. E. (2012). Determinants of Bank Profitability: An Investigation on the Turkish Banking Sector. In: Öneri Dergisi. 10(37):103-110.

3. Alexiou, C., \& Sofoklis, V. (2009). Determinants of bank profitability: Evidence from the Greek banking sector. In: Ekonomski anali. 54(182):93-118.

4. Pilloff, S. J., Rhoades, S. A. (2002). Structure and Profitability in Banking Markets. Review of Industrial Organization. 20(1):81-98.

5. Athanasoglou, P. P., Brissimis, S. N. \& Delis, M. D. (2005). Bank-specific, Industry Specific and Macroeconomic Determinants of Bank Profitability MPRA Paper, No.153.

6. Goddard, J., Molyneux, P., Wilson, J. (2004). Dynamics of Growth and Profitability in Banking. Journal of Money, Credit and Banking. 36(3):1069-1090.

7. Boyd, J. H., \& Runkle, D. E. (1993). Size and performance of banking firms: Testing the predictions of theory. Journal of monetary economics, 31(1), 47-67.

8. Naceur, S. B., \& Goaied, M. (2003, December). The determinants of bank interest margin and profitability: evidence from Tunisia. In 10th Conference of Economic Research Forum, World Bank, Marrakech (pp. 16-19).

9. Naceur, S. B., \& Goaied, M. (2008). The Determinants of Commercial Bank Interest Margin and Profitability: Evidence from Tunisia. Frontiers in Finance and Economics, 5(1):106-130.

10. Jiang, G., Tang, N., Law, E., \& Sze, A. (2003). Determinants of Bank Profitability in Hong Kong," Hong Kong Monetary Authority Research Memorandum, September. Urnal of Banking \& Finance, 35, 2881-2890.

11. Staikouras, C., \& Wood, G. (2003). The Determinants of Bank Profitability in Europe, Paper presented at the European Applied Business Research Conference.

12. Demirguc-Kunt, A., \& Huizinga, H. (1999). Determinants of Commercial Bank Interest Margins and Profitability: Some International Evidence. World Bank Economic Review, 13:379-408.

13. Athanasoglou, P. P., Brissimis, S. N., \& Delis, M. D. (2005). Bank-Specific, Industry-Specific and Macroeconomic Determinants of Bank Profitability, Bank of Greece, Working Paper No. 25.

14. Flamini, V., Mcdonald, C., \& Schumacher, L. (2009). The determinants of commercial bank profitability in SubSaharan Africa. International Monetary Fund. [Online]. Available from: https://www.imf.org/external/pubs/ft/wp/2009/wp0915.pdf [Accessed: 10th September 2014].

15. Khrawish, H. A. (2011). Determinants of Commercial Banks Performance: Evidence from Jordan. International Research Journal of Finance and Economics. 81:148-159.

16. Menicucci, E., \& Paolucci, G. (2016) Factors affecting bank profitability in Europe: an empirical investigation. African Journal of Business Management. 10(17): 410-420.

17. Ozgur, O., \& Gorus, M. S. (2016). Determinants of deposit bank profitability: evidence from Turkey. Journal of Applied Economics and Business Research. 6(3): 218-231.

18. Sharma, E., \& Mani, M. (2012). Impact of Macroeconomic and Financial Market Indicators on the Banking Sector: Some Evidence from India. International Journal of Research in Finance \& marketing, 2(2), pp.171-185.

19. Sufian, F., \& Chong, R. R. (2008). Determinants of bank profitability in developing economy: empirical evidence from the Philippines. Asian Academy of Management Journal of accounting and finance. 4:91-112.

20. Ayanda, A. M., Christopher, E. I., Mudashiru M. A. (2013). Determinants of banks' profitability in developing economy: evidence from the Nigerian banking industry. Interdisciplinary Journal of contemporary research in business. 4:155-181. 
21. Wahdan, M., \& Leithy, W. (2017). Factors affecting the profitability of commercial banks in Egypt over the last 5 year (2011-2015). International Business Management. 11(2):342-349.

22. Al-Jafari, M. K., \& Alchami, M. (2014). Determinants of bank profitability: Evidence from Syria. Journal of Applied Finance and Banking, 4(1), 17.

23. Aftab, D. T. (2015). U.S. Patent Application No. 14/426,580.

24. Hu, C., Xie, Y., Xie, Y., Liu, S., Xu, Y., Liang, L., ... \& Liu, Z. (2016). Performance of positive ion based high power ion source of EAST neutral beam injector. Review of Scientific Instruments, 87(2), 02B301.

25. Islam, M. S., \& Nishiyama, S. I. (2016). The determinants of bank net interest margins: A panel evidence from South Asian countries. Research in International Business and Finance, 37, 501-514.

26. Aydemir, C. (2016). A study on the printability properties of alkali-sized recycled papers. Science and Engineering of Composite Materials, 23(5), 565-571.

27. Lipunga, A. M. (2014). Determinants of profitability of listed commercial banks in developing countries: Evidence from Malawi. Research Journal of Finance and Accounting, 5(6), 41-49.

28. Boitan, I. A. (2015). Determinants of sustainable banks'profitability, evidence from eu countries countries. Financial Studies, 19(1).

29. Petria, N., Capraru, B., \& Ihnatov, I. (2015). Determinants of banks' profitability: evidence from EU 27 banking systems. Procedia economics and finance, 20, 518-524.

30. Mohammad, A., Suleiman, A., \& Al Khattab. (2015). A Case Study in Business Market: Banks' Profitability: Evidence from Jordanian Commercial Banks (2002-2015). International Journal of Business Management and Economic Research (IJBMER), 6(4):204-213.

31. McCauley, R. N., \& White, W. R. (1997). The euro and European financial markets. EMU and the International Monetary System, 324-88.

32. Naseem, I. (2012). Appraising Banking Sector Performance in Pakistan During Last Decade: 20012010. International Research Journal of Basic and Applied Sciences, Forthcoming.

33. Bolt, W., de Haan, L., Hoeberichts, M., Cvan Oordt, M. R., \& Swank, J. (2012): bank profitability during recessions. Journal of Banking and Finance, 36(9): 2552-2564.

34. Alessandri, P., \&Nelson, B. D. (2015). Simple banking: profitability and the yield curve. Journal of money, credit and banking. 47(1):143-175.

35. Ramlall, I. (2009). Bank-specific, industry-specific and macroeconomic determinants of profitability in the Taiwanese banking system: Under panel data estimation. International Research Journal of Finance and Economics, 34:160-167.

36. Goddard, J., Liu, H., Molyneux, P., \& Wilson, J. O. (2011). The persistence of bank profit. Journal of Banking \& Finance, 35(11), 2881-2890.

37. Kaplan, M., \& Çelik, T. (2008). The persistence of profitability and competition in the Turkish banking sector. Erciyes Üniversitesi İktisadi ve İdari Bilimler Fakültesi Dergisi, (30), 157-167.

38. Tizzani, P., Berardino, P., Casu, F., Euillades, P., Manzo, M., Ricciardi, G. P., ... \& Lanari, R. (2007). Surface deformation of Long Valley caldera and Mono Basin, California, investigated with the SBAS-InSAR approach. Remote Sensing of Environment, 108(3), 277-289.

39. Dietrich, A., \& Wanzenried, G. (2011), "Determinants of bank profitability before and during the crisis: Evidence from Switzerland", Journal of International Financial Markets, Institutions, and Money. 